\title{
Visual tourism and post-colonialism: imaginative geographies of Africa in a Portuguese travel magazine
}

\section{Eduardo Brito-Henriques}

To cite this article: Eduardo Brito-Henriques (2014) Visual tourism and post-colonialism:

imaginative geographies of Africa in a Portuguese travel magazine, Journal of Tourism and Cultural Change, 12:4, 320-334, DOI: 10.1080/14766825.2014.887722

To link to this article: http://dx.doi.org/10.1080/14766825.2014.887722

Published online: 25 Feb 2014.

Submit your article to this journal $\sqsubset$

Џ Article views: 450

Q View related articles $\square$

View Crossmark data ¿

Citing articles: 1 View citing articles $\longleftarrow$ 


\title{
Visual tourism and post-colonialism: imaginative geographies of Africa in a Portuguese travel magazine
}

\author{
Eduardo Brito-Henriques* \\ Centre for Geographical Studies/Institute of Geography and Spatial Planning, University of \\ Lisbon, Lisbon, Portugal
}

(Received 21 May 2013; accepted 17 January 2014)

\begin{abstract}
This paper is about tourism, visual culture, and imperialism in the post-colonial present. International literature on these issues has been especially focused on the experience of British and French post-colonialism. Few studies have addressed this issue regarding other post-colonial realities. This paper runs counter to that fact by analysing the visual touristic discourse produced in the post-colonial Portugal. The paper examines the way the sub-Saharan Africa is represented in a Portuguese travel photo-magazine - the Blue Travel magazine - so as to verify the extent to which the ideology of colonialism continues to shape the post-colonial touristic discourse in this former colonizing country of the southern Europe. More than 522 photographs were analysed. Using visual methodologies, the paper concludes that many aspects of the photographs contain encoded encomiastic messages of colonialism and participate in a discursive construction of Africa that was clearly shaped by an imperialist gaze. The paper suggests that not only there is an obvious nostalgia for empire in the Portuguese touristic discourse on sub-Saharan Africa, but also that many imperialist myths continue to circulate diffusely within the Portuguese post-colonial society and to shape the way sub-Saharan Africa is touristically imagined.
\end{abstract}

Keywords: post-colonialism; representations; visual culture; travel magazines; Africa; Portugal

\section{Introduction: purpose of the study and methodology}

In a message addressed to the International Conference on Tourism, Religions and the Dialogue of Cultures held in Cordoba, Spain, on 29 October 2007, Ban Ki-moon stated:

In a global environment marked by rising intolerance and cross-cultural tensions, often exacerbated by the economic divide between nations, tourism can foster spiritual and cultural respect among and between peoples, while creating economic opportunities to benefit disadvantaged populations. (The Secretary-General's Statements, available at http://www.un.org/apps/sg/ sgstats.asp?nid=2824; last accessed 12 October 2012)

Imagining tourism at the service of the more fragile populations and of the dialogue of civilizations is unquestionably appealing. Listening to these Ban Ki-moon's optimistic words with regard to the future of tourism and its role in human development, a sense of joy and hope inevitably fill us. However, many authors have raised doubts about the possibility of such a dream being accomplished. Critics counter-argue that tourism reproduces

*Email: eduardo@campus.ul.pt 
misunderstandings on otherness, reducing the people and cultures of destination places to the stereotypes circulating in the societies to which the tourists belong (see Mellinger, 1994; Morgan \& Pritchard, 1998; Selwyn, 1996). This is an obvious hindrance to such a dialogue of cultures. Furthermore, the problem seems to be aggravated when it comes to destinations in the Global South, where tourism puts people from societies with huge cultural differences, wealth disparities, and histories of atrocity and colonial domination in contact (see Carrigan, 2011; Johnson, 2010; Lisle, 2006; Morgan \& Pritchard, 1998).

Post-colonialism provides conceptual instruments that may be helpful to understand what exactly is at stake in these situations. As a critical theory set on examining the legacies of colonialism in the post-colonial societies, post-colonialism deals with culture and identity issues in previously colonized countries, as well as with cultural representations in colonizing countries about colonization and colonized peoples. The key idea of the post-colonial theory is that the end of formal and political colonialism obtained through the independence of former colonies neither put a definitive end to imperialism imperialism taken as the ideology of colonialism - nor to colonial inequalities (Said, 1994). To use the words of Sharp (2009, p. 5), 'cultural decolonisation - often referred to as the decolonisation of the mind - has been a much more difficult process' than political decolonization, or even than economic decolonization. Post-colonialism postulates that the old ideology of colonialism is still active in the post-colonial present, albeit dissimulated and diffused; imperialism has ceased to have a judicial and administrative expression; however, it continues to operate in terms of culture and through representations, producing 'imaginative geographies' of otherness (Said, 1979) that affect the way in which societies and individuals relate to each other.

Many authors have sustained that contemporary tourism constitutes an updated form of colonialism over the Global South. First, tourism induces new types of economic and political dependence. Since the 1970s, many authors have been quite critical of the role of tourism in the developing countries, stressing that tourism industry is mostly controlled by foreign companies and that these companies retain the most of the tourism benefits (Brown \& Hall, 2008; Cazes, 1989; Dash, 1989; Jaakson, 2004; Turner \& Ash, 1975). On the other hand, a number of authors influenced by post-structuralist approaches to textual analysis also have found that the touristic discourse seems to encapsulate a number of old clichés of imperialism, thus perpetuating and disseminating the ideology of colonialism (Carrigan, 2011; Caton \& Santos, 2008; Hall \& Tucker, 2004; Huggan, 2009; McRae, 2003; Sheller, 2004). Once absorbed and assumed by tourists, those clichés will go on to shape the tourists' attitudes and behaviours, acquiring an actual expression in social life and affecting the way reality is produced.

Up till now international literature on the links between tourism and post-colonialism has been largely focused on the Anglo-American post-colonial experience, or to a lesser extent on the French post-colonial experience. Rarely do such studies address the issue without relation to the British and French experiences of colonization, the two hegemonic colonizing powers of the modern European colonialism (one of the exceptions being Sarmento, 2011). The knowledge regarding how the ideology of colonialism continues to shape the touristic discourse produced within other post-colonial contexts, namely in the Southern and Eastern peripheries of Europe, which also had their own empires in the past, is quite limited.

This paper aims to solve that lacuna by examining the touristic discourse on the subSaharan Africa produced in the post-colonial Portugal. Portugal is one of those former colonizing countries of the southern periphery of Europe. Moreover, it is the exact European country with the longest colonial empire in Africa. Portuguese were the first Europeans 
to settle on the African coast in the fifteenth century. Later on, unlike the UK, France, and Belgium, whose former colonies were practically all independent by 1964, Portugal insisted on maintaining the political sovereignty over the $2,090,000 \mathrm{~km}^{2}$ of its African possessions (the current states of Angola, Mozambique, Guinea-Bissau, Cape Verde, and São Tomé and Principe), embarking on a long bloody colonial war which only ended in 1974, when the Carnation Revolution finally brought down the dictatorial regime in Portugal.

Different types of imagery could be examined concerning that purpose. In this study, the option was to focus on the visual imagery, using content analysis and semiology as methodologies. The paper follows the typical approach of media studies. Similar to Lutz and Collins (1993) in their work on National Geographic, a travel photo-magazine was chosen as primary source and its photographs were taken as the raw material for research. As the hypothesis which this paper defends is that the ideology of colonialism continues to operate actively through representations even in the non-hegemonic colonizing cultures, producing imaginative geographies of otherness that pervade all types of discourse and of social milieu (although in refracted ways), the option was to choose a self-claimed eco-friendly, 'free-minded' and alternative Portuguese travel magazine - the Blue Travel, in which, in principle, it would be less likely to find inscriptions of the imperialist thought. Therefore, a thorough observation of the 88 editions of the Blue Travel magazine published between 2003 and 2011 was conducted, which permitted identifying 17 reports on sub-Saharan Africa, totalling 374 pages, from which 522 photos were gathered.

The first research step consisted in doing a quantitative content analysis of the photographs (for more on this method, see Rose, 2007). Content analysis is the most adequate method to handle large number of images with some degree of consistency, as Lutz and Collins (1993) defended. It basically helps researchers discern patterns and themes within a sample of images based on the repetition of certain visual elements. In this paper, content analysis was applied so as to identify the main traces of the Blue Travel representation of Africa and to verify the extent to which it encompasses imperialist racial stereotypes and colonial apologetics. Content analysis, however, is not enough to interpret images. As Rose (2007, p. 72) asserted, 'numbers do not translate easily into significance'. A multi-method approach is highly recommended for interpreting visual culture. Accordingly, content analysis was complemented by a semiotic analysis of photos, the main goal of which was to elucidate underlying meanings related to the mythology of colonialism.

\section{Visual tourism, photographs, and power}

Although the most recent approaches of tourism drawn on the phenomenological concept of embodiment are critical of the hegemony of the gaze in tourism and have been demonstrating how tourists' consumption of place are multisensory and corporeal (Rakic \& Chambers, 2012), there are no doubts that the touristic discourse is fundamentally visual. Images are critical in tourism. First, they are decisive in choosing a destination. Secondly, images create expectations about what may be seen and done in destinations, influencing the way tourists experience space and place (Brown \& Hall, 2008; Chon, 1990; Molina, Gómez, \& Martín-Consuegra, 2010; Su, 2010).

Photographs play a prominent role among the tourism imagery. A number of studies have shown that photos are the most influential and effective elements of tourism brochures in moulding destination images (Molina \& Esteban, 2006). Photos also help create and sustain tourists' memories (Cramshaw \& Urry, 1997). A research into the photographic stuff circulating in the touristic discourse appears, thus, broadly justifiable. 
Most of the work on the visual culture of tourism and travelling has focused on the analysis of promotional materials published by official authorities and tourism companies, particularly brochures and posters (Ateljevic \& Doorne, 2002; Buzinde, Santos, \& Smith, 2006; Dann, 1996; Echtner \& Prasad, 2003; Francesconi, 2011; Jenkins, 2003; Saidi, 2008; inter alia). Nevertheless, it is not certain that these are the most decisive elements in shaping destination images. The formation of destination images is not based on one single source; they are normally formed by means of overlapping and conjugating information from several sources, produced by different agents, which frequently escape the control of local authorities and marketers. Literature refers to controllable and uncontrollable sources of information, according to the degree of autonomy in relation to marketers and local stakeholders. Studies also suggest that the more uncontrollable the sources are, the most effective they are in shaping destination images, since they are regarded by consumers as being independent and unbiased, consequently more reliable (McCartney, Butler, \& Bennett, 2008). Mass media, such as TV, cinema, Internet, and the press, are among the information sources that seem to be more influential (Camprubí, Guia, \& Comas, 2008; Govers, Go, \& Kumar, 2007; Kim \& Richardson, 2003; Stepchenkova \& Morrinson, 2006).

The decision to use photographs from a travel magazine in this paper stems primarily from what has previously been mentioned. Another motive is linked to the belief that in the contemporary information society, the consumption of destination images through mass media configures a new form of tourist experience detached from 'real' tourism. Urry (1995, p. 179) referred to this as 'armchair travel'. Visual tourism phrases it another way. It means a passive or contemplative form of place consumption that involves neither mobility nor an embodied experience of space, which is intimately related to the 'lens culture' in which we live immersed today (Coleman, 1998). Many readers who consume travel magazines are not necessarily planning their trips or deciding on destinations, but merely using magazines as a means to relax and withdraw themselves and to enjoy the pleasure of a disembodied experience of exotic places. Visual tourism has been made possible due to the fact that the act of consuming has ceased to imply a physical appropriation of stuffs in the advanced consumption societies: today we can simply 'consume with our eyes' as Willis (1991, p. 31) stated.

Photographs are the most common elements of the lens culture in which we live today. Nevertheless, they are probably the most problematic components of that lens culture too, since they subversively challenge the concept of truth and establish a staged authenticity (MacCannell, 1999). Photos suggest that their content is a pure expression of reality and not simply one of the several possible representations of such reality, but, indeed, 'Photographs do not "show how things look", since there is no one way that anything looks' (Coleman, 1998, p. 57).

Photographs, visual consumption, and power are enmeshed in a web of complex relations. As clearly explained by the Gramscian theory, the power of an ideology depends on its ability to present some particular interpretations of social life as unbiased and neutral reflections of reality. The key lies in the ability to convey the idea that such particular interpretations of the world are unquestionable facts, or 'natural' things, thus releazing them from critical scrutiny. Ideology turns into totalizing when such narrative is so deeply ingrained in mentalities that it interposes itself as a filter in the experience of reality. Understandably, due to the myth of neutrality surrounding them, photos are particularly effective instruments in that naturalization and totalization of ideology.

The consumption of travel photo-magazines is not alien to this relationship involving photography, ideology, and power. The photos of travel magazines belong to the universe of visual culture. They are shaped by a socially produced visuality that is common to other 
forms of visual discourse. Such images are not unscathed by cultural hegemonies. They are also arenas within which hegemony is expressed and reproduced. As with all forms of touristic discourse, these representations contribute towards perpetuating ideologies and participate in that which Ateljevic and Doorne (2002, p. 651) referred to as the 'circularity of knowledge and power'.

\section{The touristic imagery of Africa in Blue Travel}

\section{The Blue Travel magazine and its originality}

The choice of the Blue Travel magazine for this study may be justified by the unique position it occupied within the Portuguese panorama of publications.

The periodical market in Portugal is fragile. Portugal has a population of 10.5 million inhabitants, among whom, in the people aged 15 or over, only $50-55 \%$ consume magazines (Marktest, 2011; the average trimestral viewings registered since 2003 oscillate during this interval). This is equivalent to around 4.5 million regular readers. Furthermore, they are readers who purchase few magazines. Throughout the entire year of 2009, 97,728,180 magazine editions were sold in Portugal (Pordata, 2011), corresponding to an average of just 1.7 magazines per reader per month.

The tourism and travel magazine segment occupies a modest position in the magazine market in Portugal. In 2001, the consumption of magazines in this segment was limited to 400,380, while in 2010 the figure was around 545,130 (APCT, 2011). Despite this increase, the tourism and travel segment within the overall total of circulating magazines always fell short to $0.5 \%$, and the national supply within this segment is reduced to a handful of magazines.

Due to the magazine market size in Portugal, capital tends to be strongly concentrated in a small number of companies. Companies have tried to stay in business by merging other companies, by acquiring smaller companies, or through the integration in conglomerates with interests in a broad range of business areas. In the tourism and travel segment, all the shares are today in the hands of large financial groups. While it lasted, from 2003 to 2011, Blue Travel was an exception. Unlike its competitors, it remained an independent editorial project belonging to a small publishing house - the Blue Media.

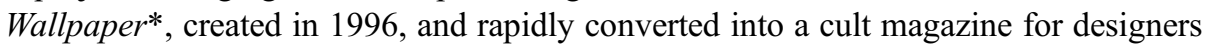
and advertisers acted as an inspiration for the Blue brand magazines, which ranged from lifestyle (Blue Living), decoration and design (Blue Design), to travel (Blue Travel). As was the case with the Wallpaper*, the Blue Travel magazine stood out from the very beginning for its elegant but jovial modern graphic design, its direct and informal language, and its use of recycled paper. Condé Nast Traveller was another reference for Blue Travel. Like this North American luxury publication, which chose the motto 'Truth in Travel' for its brand image, Blue Travel adopted the status of 'a magazine for travellers and not tourists', for informed and open-minded people accustomed to travelling who - in the words of its editor - 'avoid the flocks of tourists and look for something more authentic' (interview with Rosário Sá Coutinho, editor of Blue Travel, on 24 February 2011). Therefore, on a par with Condé Nast Traveller, Blue Travel waived descriptions on the predictable and well-known aspects of destinations, endeavouring to suggest distinguished and alternative experiences and to show the more unknown and exclusive sides of destinations. Although independent travellers were the target readers, they were not the backpackers from the Lonely Planet; the Blue Travel target readers were affluent consumers who wanted to enjoy life and to have sophisticated relaxing experiences in select and fashionable places. 
The end of the Blue Travel magazine in 2011 was the outcome of the growing difficulty experienced by Blue Media to ensure survival within the harsh recession experienced by the Portuguese economy from 2008 onwards, when the global recession and the State debt crisis of the Euro zone have begun enforced highly recessive budget correction measures in Portugal. During the years 2008, 2009, and 2011, the GDP in Portugal underwent negative growth and people had a significant loss of purchasing power. From 2007 to 2009, there was a decrease of 22,102,600 magazines sold in Portugal per year. Within a framework of lower demand, lower publicity revenue and more difficult access to credit, Blue Media was forced to close down, bringing the Blue Travel publication to an end.

\section{The places unveiled by Blue Travel and the politics of authenticity}

In this study, all the photos published in the Blue Travel reports on the sub-Saharan Africa have been taken into consideration. Images play an extremely important role in travel magazines, which is why no less than 522 photographs were published. One hundred and sixty-three of these photos were large, occupying whole pages and even double pages. The others were mainly sized at around $14 \times 16 \mathrm{~cm}$, or $8 \times 6.5 \mathrm{~cm}$, and only rarely of a smaller dimension.

Although this figure corresponds to a lot of material in absolute terms, in fact it is very little in relation to the amount of reports published by Blue Travel. Seventeen reports mean an average rate of one publication on the sub-Saharan Africa in every six editions of the magazine. In contrast, European destinations appeared in almost every edition, and even other remote tropical and subtropical destinations, such as Brazil or south-east Asia, were featured more frequently.

Such relative obscuration of the sub-Saharan Africa in Blue Travel is not incomprehensible. In fact, the region also occupies a very marginal position in the geography of international travels: in 2009, the sub-Saharan Africa concentrated a mere 3.3\% of the international tourist arrivals around the world, and $2.2 \%$ of the international tourism revenue (UNWTO, 2011).

The presence of the sub-Saharan Africa on the pages of Blue Travel was limited to the archipelagos of Cape Verde and São Tomé and Principe, which have been former Portuguese colonies, and to a few locations in South and East Africa where wild life sanctuaries and natural parks may be found (Kruger Park, Masai Mara and Serengeti, Okavango Delta, Lake Malawi, Victoria Falls, Namib Desert). The Indic beaches were also the focus of attention (Bazaruto and Quirimbas Islands, in Mozambique; Zanzibar; Seychelles). On the other hand, according to Blue Travel, the many thousands and thousands of square kilometres covering the Sahel Belt and the Horn of Africa, the Gulf of Guinea, and the Central Africa were a 'blank space' where there was nothing worthy of mention (Figure 1).

In order to understand what constituted the African imagery of Blue Travel, the photographs were categorized according to their themes. Each image was carefully examined for identifying exhaustive, exclusive, and replicable coding categories as required by content analysis (on this methodology, see Rose, 2007). Thus, four basic categories of photos regarding their content were identified, which, not surprisingly, correspond to the four broad themes of the western figurative painting: landscape images, genre scenes (mainly 'domestic' environments or interior spaces), portraits, and still life (small objects, flowers, fruit, conches and shells, food). In fact, as Schroeder (2002) had already previously shown, there has been a strong discursive unity in the western visual culture over the last centuries. From the paintings of the Dutch Golden Age to the modern publicity photography, a systematic repetition of the same basic themes and compositional models of images can be found. This aesthetic coherence and continuity of the modern western visual culture 


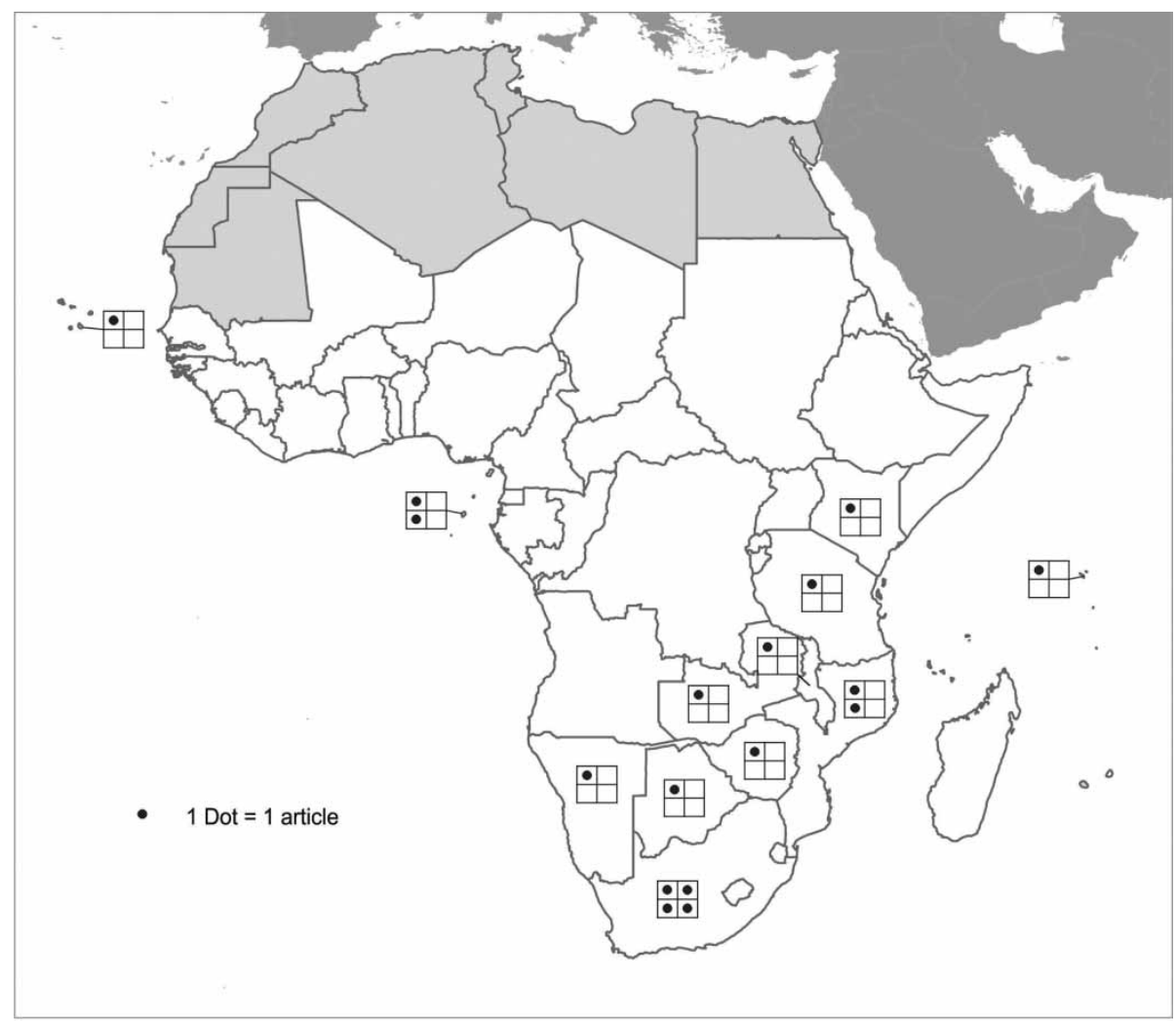

Figure 1. Reports on the sub-Saharan Africa published in Blue Travel by country, 2003-2011.

explains why the Blue Travel photographs could be grouped in those four basic categories of images.

Still life and portrait categories were the least represented in the set of published images on the sub-Saharan Africa. Altogether they totalled a mere $17.6 \%$ of the published photos (Table 1). The genre photos occupied a little more than $20 \%$ of the images. Almost all of them were interior photos taken in hotels, resorts and restaurants (113 of the 119 photos of this type).

Like other magazines, Blue Travel sets out to attract the sponsorship of hotel groups and tour operators, which offered accommodation to journalists in exchange for these types of references. Interior photos of hotels and resorts are, thus, a form of disguised publicity. Nevertheless, these photos also actively participate in the construction of an imperialist

Table 1. Main themes of the Blue Travel photos on the sub-Saharan Africa.

\begin{tabular}{lcr}
\hline & Number & $\%$ \\
\hline Landscape pictures & 311 & 59.58 \\
Genre scenes & 119 & 22.80 \\
Still life & 34 & 6.51 \\
Portraits & 58 & 11.11 \\
Total & 522 & 100.00 \\
\hline
\end{tabular}


imaginative geography of the sub-Saharan Africa. Such interior photos evoked the romantic and adventurous imagery of the nineteenth-century explorations and the big-game hunting, encoding an obvious nostalgia for empire and colonization. The architecture and decoration of the resorts were dominated by the use of African and colonial motifs. Wooden decks with perfectly laid tables overlooking the savannah, beds cloistered by mosquito nets, canvas loungers and tents, leopard and zebra skins serving as rugs, and oil lamps and torches were repeatedly used features in these photos and acted as metonymies of the Scramble for Africa. The interior ambiances shown in the rather cinematographic, quasi-baroque photos of Blue Travel were the ambiances of novels such as Green Hills of Africa by Hemingway or Out of Africa by Karen Blixen. Indirectly, these photos told a glamorous story of adventure and bravery. In connotative terms, they referred to the heroic endeavour of the white European man to dominate the savage black continent.

As to be predicted, the landscape photos formed most of the visual material on the subSaharan Africa published in Blue Travel (59.6\% of photographs). These photos were coded again on the basis of the depicted environments for refining their classification. Four coding categories were thus established, each corresponding to a different type of habitat: beach, savannah/jungle, desert, and urban habitat. Savannah and jungle landscapes and beaches appear more frequently, each corresponding to around a quarter of all the images. As for the rest, around $90 \%$ of the landscape photos were of natural landscape, also including a small number of desert photos (3.4\% of the total number of photos) (Table 2).

The Blue Travel imagery of sub-Saharan Africa reproduces the myth of a pristine world, savage and brutal, but also seductive and voluptuous. The photos oscillate between the archetype of the seas of South, with their turquoise waters and coconut trees bowing over the white sands, and the archetype of black Africa, the epitome of an eternally virgin, wild, and primitive land. Among the images of natural landscapes, only half of them featured people or displayed indirect references to their presence on the landscape (jeeps in the distance, in the savannah; isolated bungalows, nestled between the coconut trees on the beach; yacht sails, inflated by the wind off the deserted coastlines). These images omitted the fact that Africa is nowadays a broadly urbanized continent, where over half the population lives in urban agglomerations, and where mega-cities are growing at a galloping rate. In the Blue Travel photos of Africa, there were hardly any cities, and almost no sign of traffic or crowded markets, or even cultivated fields. All these absences were 'significant silences' (Echtner \& Prasad, 2003, p. 673), deliberate omissions contributing to an imaginative geography of Africa that rejected part of its materiality and 'real' geography.

The few urban images that the Blue Travel reports depicted were almost all related to the former Portuguese colonial empire. While in the pictures previously described, few or no features distinguish the Blue Travel visual discourse on Africa from that you can find in any British or French travel magazine, these images tell a story significantly different. In

Table 2. Type of habitat depicted in the Blue Travel landscape photos on the sub-Saharan Africa.

\begin{tabular}{lcr}
\hline & Number & $\%$ \\
\hline Beach & 126 & 40.51 \\
Savannah/jungle & 133 & 42.77 \\
Desert & 18 & 5.79 \\
Urban habitat & 34 & 10.93 \\
Landscape photos (total) & 311 & 100.00 \\
\hline
\end{tabular}


these photos, Lusitanism is clearly put in evidence. These photos build up and reproduce an imaginative geography of Africa in which it appears as a kind of mere tropical extension of the Portuguese territory. Urban spaces revealed in the photos of Blue Travel are full of signs which can be easily deciphered by a common Portuguese reader as legacies of 'its' own national culture. They are dominated by the image of long and narrow streets with monotonous rows of whitewashed plain style houses, covered with the typical Portuguese ceramic tiles roofs, comparable to those found in any provincial town of Portugal. Basically, they reproduce the vernacular architecture and the typical urbanscape that the Portuguese replied in their former colonies, from Brazil to India. All these references contribute to create a strong cultural identity and, at the same time, to raise a clear sense of ownership and appropriation. On the other hand, many of these photos display the image of an oldfashioned and out-dated modernity, as if cut short by decolonization. Urban photos expressed a nostalgia for empire, enveloped in a pleasant aesthetics of abandonment: semi-ruined Portuguese churches, decadent colonial mansions surrounded by abandoned gardens, ironmongers such as those found in Portugal 50 years ago, and old advertisements for the Sandeman Port wine, a cliché of the 1950s and 1960s Portuguese visual culture, converted in this context onto an icon of the lusotropicalism adapted to a post-colonial rhetoric (on lusotropicalism, see Pimenta, Sarmento, \& Azevedo, 2011).

Part of the Blue Travel African imagery recovers and resumes the theme of lusotropicalism and, accordingly, reflects and reproduces much of the old Portuguese colonialist myths. Lusotropicalism was a theory initially developed by the Brazilian anthropologist Gilberto Freyre in the 1930s to explain the apparent success of racial relations in Brazil as well as the prevalence of the cultural and biological hibridization, which supposedly characterized the same country. Having studied in USA, Gilberto Freyre had noticed a higher prevalence of mixed race in the Brazilian society over the North American. Thus, he developed the argument that the Portuguese were better at mixing with other native populations and merging cultures than other European people. Freyre developed the thesis that the Portuguese had a 'natural' ability to relate to indigenous people and that Portuguese colonization was more 'humane', comprehensive, and 'spiritual' than the Spanish or English colonization, for instance. While the English colonialism were characterized by a puritan social distance between the colonizers and the colonized, and the Spanish colonization encompassed the physical and cultural extermination of the colonized, lusotropicalism stands that the Portuguese colonialism had generated a much more harmonious relation between colonizers and colonized, producing an original, multi-racial, and multi-continental civilization in the tropics based on a mixed identity with Portuguese roots.

Lusotropicalism theory was introduced in the official doctrine of Portuguese colonialism in the 1940s. This theory was welcomed by Portuguese social scientists and was politically used in the dictatorship of Salazar as a 'scientific' justification for the permanence of Portugal in the tropics (Pimenta et al. 2011). Lusotropicalism sustained the idea that the colonies were not possessions but, rather, an integral part of a multi-continental and multi-racial Portuguese nation, thus becoming particularly useful when the international pressure on Portugal in favour of decolonization began to emerge. Based on lusotropicalism theory, and in order to justify the perpetuation of Portuguese colonialism, the imperialist Portuguese rhetoric has been adapted in 1951, shaping the way as Portuguese imagined themselves and their empire from then onward: the expression 'colony' was banned and replaced by 'ultramarine province', the term 'Portuguese Colonial Empire' became 'Portuguese Overseas Territories' in legislation, school textbooks, and maps, and Portugal was officially declared 'one only country from Minho to Timor'. As Alexandre (1999) clearly explained, this means that Portuguese imperialism has merged an imperialist 
logic and a nationalist logic in its self-legitimation discourse, acquiring some particular features.

Post-colonial theory has stressed the importance of difference in colonial discourse. Imperialism is grounded on the idea of a binary us/them with clear and strict boundaries separating each side. This anthropological discontinuity defined by race needs to be produced so that colonialism can justify itself. This is why Bhabha (1983, p. 23) referred to 'the difference of colonial discourse as an apparatus of power'. The 'exoticization' of non-European people and cultures, which appears as a fundamental strategy in the ideological construction of otherness, serves to radicalize the perception of difference while equally producing a power imbalance between the author of discourse, through which he/she assumes him/herself as the norm, and the subject of discourse, seen as an opposite or negative and, thus, a distortion of the norm. Depicting the other as primitive, ignorant, or licentious is a way of affirming oneself as advanced, enlightened, and virtuous, and this is how colonial domination is made to seem acceptable and even recommendable (Said, 1979).

Bhabha (1983) explained that the 'productivity' of colonial discourse as a power device depends on the capacity to avoid the use of images with an openly negative connotation in representing otherness, opting for ambivalent signs against which it is far more difficult to offer resistance. The African imagery of Blue Travel falls into this category. By referring to an untouched nature, spared from modernity and civilization, a reference is also being made to primitivism and backwardness. For the modern western mentality, backwardness is something that has to be corrected. An Africa presented to visual consumption as something beautiful but primitive, savage, and deserted is an Africa which once again invites occupation, offering itself to be enjoyed and civilized, and which, as suggested by Echtner and Prasad (2003), is still haunted by colonial exploration.

\section{Ghosts of the colonial race mythology}

By following the methodology used by Buzinde et al. (2006), the photos of Blue Travel were examined to ascertain how indigenous people (blacks) and tourists (whites) were represented, and the extent to which racial stereotypes were present in those photos. As the Buzinde's et al. (2006) study proposes, two key indicators were considered: clothing and the attitude of the characters represented in the photographs.

The coding categories used for the classification of clothing were obtained from the analysis of the images themselves. While going through the photographs, it became clear that there was a repeated pattern behind the way the different people were presented in them. This pattern was based on four basic types of clothing: swimwear (bathing suit with or without t-shirt for men, bikini and pareu for women); informal clothing (with emphasis on cotton and light linen, loose, comfortable clothing); ethnic and safari clothing (khaki shorts and shirts, sun hat, boots); and work uniforms. The distribution of these dress types among the two human groups was unequal and cross-tabulation confirmed that this variation was not random but, rather, significantly related to ethnicity $\left(X^{2}=76.29, p<\right.$ $0.05)$ : while the white people appeared mainly in informal swimwear, the black people emerged in ethnic or safari clothing or in a work uniform (Table 3). This disparity confirmed the imbalance between the blacks and the whites in the political economy of tourism. Represented in informal clothing or swimwear, the whites corresponded to the image of the tourist; the blacks, on the other hand, appeared as service providers (in uniform), or were reduced to mere objects for tourist consumption, as synecdochical signs of an Africa reduced to primitive tribes and big-game hunting (Masai men, Himba women, the black escorts wearing safari clothing). 
Table 3. Clothing of the white and black people depicted in the Blue Travel photos on the subSaharan Africa.

\begin{tabular}{|c|c|c|c|c|c|}
\hline & Swimwear & Ethnic and safari clothing & Informal clothing & Work uniforms & Total \\
\hline \multicolumn{6}{|c|}{ Caucasian/white people } \\
\hline Observed & 39 & 17 & 84 & 5 & 145 \\
\hline Expected & 32.28 & 34.47 & 57.45 & 20.79 & 145.00 \\
\hline Percentage & 26.90 & 11.72 & 57.93 & 3.45 & 100 \\
\hline \multicolumn{6}{|c|}{ African/black people } \\
\hline Observed & 20 & 46 & 21 & 33 & 120 \\
\hline Expected & 26.72 & 28.53 & 47.55 & 17.21 & 120.00 \\
\hline Percentage & 16.67 & 38.33 & 17.50 & 27.50 & 100.00 \\
\hline Chi square & \multicolumn{5}{|c|}{$76.29, p<0.05, \mathrm{df}=5$} \\
\hline
\end{tabular}

In order to understand the physical attitude associated with the basic 'epidermal schema' black/white, the coding categories considered in Buzinde et al. (2006) were replicated, namely photos of people posing for the camera (portraits), people physically passive (thinking, reading, resting, etc.), and scenes involving physical activity (people dancing, playing instruments, running, swimming, working, etc.). The initial assumption was that the images would be affected by racial stereotypes and colonial myths if the different ethnic groups were attributed different roles, particularly if some seemed to be more associated with images of domination and intellectual activity, and others with servitude and muscular activity. As was the case in the above-mentioned study, it was also possible to verify significant variations in the attitude by which both blacks and whites were depicted in the Blue Travel photos $\left(X^{2}=64.92, p<0.05\right)$ : the blacks appeared more frequently posing for the photograph (converted into visual consumption objects), and in physical activities, while the whites were more represented in physically passive activities (Table 4).

In a study on the cultural meanings contained in the photographs produced by tourists during the trips, Caton and Santos (2008) found that photos speak primarily about differences and that tourists and hosts tend to be conceived in terms of basic binary oppositions such as Master/Servant or Subject/Object. In the Blue Travel photos, the same basic structure of signification may be observed too. The fact that indigenous people appear in work uniform or ethnic clothing, and are more frequently represented posing for the camera or in physical activities performed for the satisfaction of white tourists, is a reflection of this relational logic. The fact that it is common for white characters to be photographed from behind in

Table 4. Attitude of the white and black people depicted in the Blue Travel photos on the subSaharan Africa.

\begin{tabular}{|c|c|c|c|c|}
\hline & Posing & Physically active & Physically passive & Total \\
\hline \multicolumn{5}{|c|}{ Caucasian/white people } \\
\hline Observed & 24 & 35 & 86 & 145 \\
\hline Expected & 42.68 & 47.60 & 54.72 & 145.00 \\
\hline Percentage & 16.55 & 24.14 & 59.31 & 100.00 \\
\hline \multicolumn{5}{|c|}{ African/black people } \\
\hline Observed & 54 & 52 & 14 & 120 \\
\hline Expected & 35.32 & 39.40 & 45.28 & 120.00 \\
\hline Percentage & 45.00 & 43.33 & 11.67 & 100.00 \\
\hline Chi square & \multicolumn{4}{|c|}{$64.92, p<0.05, \mathrm{df}=4$} \\
\hline
\end{tabular}


the Blue Travel images, observing the landscape, is also rather enlightening; this type of iconic composition in which the tourist is depicted only as a vigilant figure in a kind of virtual panoptic is a subtle metaphor for the power of the white man over the African landscape - a power exerted through distant, discreet supervision - as well as serving to establish a personal identification with the magazine readers, since they both share the same point of view.

A brief analysis of the semiology of these photos makes it possible to point out one or two other interesting aspects on the way race is portrayed in the magazine photographic material.

One of these aspects is related to how the black and the white people are photographed together in the images. Although there are very few photos showing interaction of blacks and whites (only in $7.9 \%$ of the photos with human figures), whenever these scenes took place it was common for the blacks to appear in the background or on a lower level, as secondary to the whites (normally positioned on a deck, on top of a stairway, or sitting on the hood of a Jeep).

Another interesting aspect is related to the symbolic relationship of the black with the image of a child. There are also very few photos of children in Blue Travel $(12.8 \%$ of the photos with people), but the vast majority of images with children depict black children $(91.2 \%)$. This fact triggers a mental association to such an extent that the black child becomes a syntagmatic sign and a metonymic evocation of the black person as a child. The stereotype of the black, indefinitely child-like, naïve (or ignorant?), carefree (or irresponsible?), and sentimental (or immoderate?), serves to confirm the need for a tutelary figure to discipline and educate. As in opposition to the child, this figure could only be an adult, in opposition to the black it would 'naturally' be a white person.

\section{Conclusion}

The identifying mark with which the Blue Travel magazine intended to differentiate itself in the Portuguese editorial panorama consisted of a genre that could be summed up as hippiechic, elegant and irreverent, trendy and cool. This feature was transported to the pages of the magazine in many ways: in the use of jovial, educated but informal language, of trim and cheerful graphic design, and of recycled paper; and through the photographs, in which tourists who appear portrayed are invariably young, natural looking but cared (long wavy hair, tanned skin), and wear casual and comfortable clothing (linen shirt or tunic or cotton scarves, shorts, flip-flops, etc.). Post-materialism, cosmopolitanism, tolerance, and ecology were key words in the construction of the brand image of Blue Travel, which also enjoyed displaying its financial independence in relation to large editorial groups as a trophy and guarantee of freedom. At first glance, this does not seem congruent with the perpetuation of the old ideology of colonialism. However, the analysis of the Blue Travel photos on the sub-Saharan Africa showed something quite different. As noticed above, a sweet nostalgia for empire pervades many of the Blue Travel photos on the subSaharan Africa. Several aspects of the compositional model of images and a large part of the signs contained therein encoded encomiastic messages of colonization and imperial domination and participated in a discursive construction of otherness that was clearly shaped by imperialism and its racial stereotypes. If we believe that the visual imagery in Blue Travel reproduces meta-codes that shape the society in which this visual discourse is produced, thus we need to conclude that imperialism as ideology continues to shape the imaginative geography of Africa in the post-colonial Portugal and that the mythology of colonialism continues to operate actively through representations across all types of discourse and of social milieu. 
In Portugal, the assumption that the semi-peripheral condition of the country conferred specific features upon its colonialism has been dominant (see Ribeiro, 2002; Santos, 2002, 2009). The fact that the centre of the empire was simultaneously a periphery within the European context and, hence, a subordinate power in relation to other colonial power centres is, according to that assumption, one of the original features of Portuguese colonialism. Such subordination triggered the country to develop a rather singular type of identification and relationship with its empire. Portuguese imperialism has merged in a peculiar way an imperialist logic and a nationalist logic in its self-legitimation discourse. Such tendency has been particularly stressed in the second half of the twentieth century, when the stubborn refusal of the Salazar dictatorship to decolonize the African territories under its administration led to the adoption of lusotropicalism as the key principle of the Portuguese imperialist ideology.

The analysis of the Blue Travel photos confirms that this apparent peculiarity of the Portuguese imperialism continues nowadays to shape the imaginative geography of Africa. In fact, the Portuguese post-colonial visual discourse on Africa still reflects in part the myth of a multi-continental Lusitanism. In the light of this, some spaces of the former Portuguese colonies, particularly the small towns, appear as a kind of mere tropical extensions of the Portuguese territory. One cannot conclude, however, that this is the dominant feature of the Blue Travel's imaginative geography of the Sub-Saharan Africa. In fact, broadly speaking, the messages contained in the Blue Travel photos do not depart significantly from those you can find in any British or French magazine travel. The analysis of the Blue Travel photos showed that the Africa portrayed in this magazine was mostly skewed by the same fantasies of emptiness, wildness and primitivism, adventure, and bravery that we found in other international travel magazines. The photos ignore the fact that modernity, urbanization, and globalization are also currently dominant forces in Africa, wherein they mould landscape and social life in a similar way to many other parts of the world.

All these absences are significant silences that tell a story of prejudice and can be related to the old colonial mythology and the legacies of an imperialist gaze. Whenever the cultures of the Global South are portrayed as exotic, primitive, servile, and dependent in the touristic discourse, an advanced and powerful North is covertly exalted, showing itself off as indispensable to the modernization and progress of those regions and societies (Lutz \& Collins, 1993). This 'exoticization' of difference leads to a perpetuation of inequality, as stated by McRae (2003): by insisting on the idea of an exotic authenticity, 'Non-modern cultures are not allowed to progress, to grow and change. They are placed in stasis, always ready and available for "Western" consumption of an imagined, nostalgic past' (p. 239).

As noted by Smith and Duffy (2003), there are always fanciful distortions in the representations of destinations that are particularly sensitive when referring to places in the Global South, since 'local landscapes, cultures and practices are presented in a particular way to appeal to Northern holidaying tastes' (p. 116). This means that there is never a total adherence of the destination images to the real social life in those places, but rather a correspondence with the archetypes and ideals imagined by tourists as being the 'authentic' character of destinations. Smith and Duffy (2003, p. 117) define such fake authenticity "as something that offers itself to the tourist as a "sign of itself".

The Africa portrayed in this magazine was, as to be concluded, skewed by the same basic fantasies that shape the imaginative geographies of Africa reproduced in other international travel magazines or in the tourist brochures. All of them speak the same language of prejudice and fake authenticities, suggesting that a global post-colonial touristic discourse dominates over the particularities of the different post-colonialisms. 


\section{References}

Alexandre, V. (1999). O império e a ideia de raça (séculos XIX e XX) [The empire and the idea of race (19th and 20th centuries)]. In J. Vala (Ed.), Novos racismos: Perspectivas comparativas [New racisms: Comparative approaches] (pp. 133-144). Lisbon: Celta Editora.

APCT. (2011). Estatísticas da Associação Portuguesa de Controlo de Tiragem e Circulação [Statistics of the Portuguese association for publishing audience control]. Retrieved November 29, 2011, from http://www.apct.pt/Analise simples.php

Ateljevic, I., \& Doorne, S. (2002). Representing New Zealand: Tourist imagery and ideology. Annals of Tourism Research, 29, 648-667.

Bhabha, H. (1983). The other question ... Homi K. Bhabha reconsiders the stereotype and colonial discourse. Screen, 24(6), 18-36.

Brown, F., \& Hall, D. (2008). Tourism and development in the Global South: The issues. Third World Quarterly, 29, 839-849.

Buzinde, C. N., Santos, C. A., \& Smith, S. L. J. (2006). Ethnic representations: Destination imagery. Annals of Tourism Research, 33, 707-728.

Camprubí, R., Guia, J., \& Comas, J. (2008). Destination networks and induced tourism image. Tourism Review, 63, 47-58.

Carrigan, A. (2011). Postcolonial tourism: Literature, culture, and environment. New York, NY: Routledge.

Caton, K., \& Santos, C. A. (2008). Closing the hermeneutic circle? Photographic encounters with the other. Annals of Tourism Research, 35, 7-26.

Cazes, G. (1989). Les nouvelles colonies de vacances? Le tourisme internationale à la conquête du Tiers Monde [The new colonies for holidays? The international tourism trying to conquer the Third World]. Paris: Ed. L'Harmattan.

Chon, K. S. (1990). The role of destination image in tourism: A review and discussion. The Tourist Review, 45(2), 2-9.

Coleman, A. D. (1998). Depth of field: Essays on photography, mass media, and lens culture. Albuquerque: University of New Mexico Press.

Cramshaw, C., \& Urry, J. (1997). Tourism and the photographic eye. In C. Rojek \& J. Urry (Eds.), Touring cultures: Transformations of travel and theory (pp. 176-195). Oxon: Routledge.

Dann, G. (1996). The people of tourist brochures. In T. Selwyn (Ed.), The tourist image: Myths and myth making in tourism (pp. 61-81). New York, NY: Wiley.

Dash, D. (1989). Tourism as a form of imperialism. In V. L. Smith (Ed.), Hosts and guests: The anthropology of tourism (pp. 37-51). Philadelphia: University of Pennsylvania Press.

Echtner, C. M., \& Prasad, P. (2003). The context of third world tourism marketing. Annals of Tourism Research, 30, 660-682.

Francesconi, S. (2011). Images and writing in tourist brochures. Journal of Tourism and Cultural Change, 9, 341-356.

Govers, R., Go, F. M., \& Kumar, K. (2007). Promoting tourism destination image. Journal of Travel Research, 46, 15-23.

Hall, M., \& Tucker, H. (2004). Tourism and postcolonialism: An introduction. In M. Hall \& H. Tucker (Eds.), Tourism and postcolonialism. Contested discourses, identities and representations (pp. 124). London: Routledge.

Huggan, G. (2009). Extreme pursuits: Travel/writing in an age of globalization. Ann Arbor: University of Michigan Press.

Jaakson, R. (2004). Globalisation and neocolonialist tourism. In M. Hall \& H. Tucker (Eds.), Tourism and postcolonialism. Contested discourses, identities and representations (pp. 169-183). London: Routledge.

Jenkins, O. (2003). Photography and travel brochures: The circle of representation. Tourism Geographies, 5, 305-328.

Johnson, P. C. (2010). Writing liminal landscapes: The cosmopolitical gaze. Tourism Geographies, $12,505-524$.

Kim, H., \& Richardson, S. L. (2003). Motion picture impacts on destination images. Annals of Tourism Research, 30, 216-237.

Lisle, D. (2006). The global politics of contemporary travel writing. Cambridge: Cambridge University Press.

Lutz, C. A., \& Collins, J. L. (1993). Reading national geographic. Chicago, IL: University of Chicago Press. 
MacCannell, D. (1999). The tourist: A new theory of the leisure class. Berkeley: University of California Press.

Marktest. (2011). Bareme-Imprensa [Barometer-Press]. Retrieved November 29, 2011, from http:// www.marktest.com/wap/a/n/id 17f1.aspx

McCartney, G., Butler, R., \& Bennett, M. (2008). A strategic use of the communication mix in the destination image-formation process. Journal of Travel Research, 47, 183-196.

McRae, L. (2003). Rethinking tourism: Edward Said and a politics of meeting and movement. Tourist Studies, 3, 235-251.

Mellinger, W. (1994). Towards a critical analysis of tourism representations. Annals of Tourism Research, 21, 756-779.

Molina, A., \& Esteban, A. (2006). Tourism brochures: Usefulness and image. Annals of Tourism Research, 33, 1036-1056.

Molina, A., Gómez, M., \& Martín-Consuegra, D. (2010). Tourism marketing information and destination image management. African Journal of Business Management, 4, 722-728.

Morgan, N., \& Pritchard, A. (1998). Tourism promotion and power. Creating images, creating identities. Chichester: John Wiley \& Sons.

Pimenta, J. R., Sarmento, J., \& Azevedo, A. F. (2011). Lusotropicalism: Tropical geography under dictatorship, 1926-1974. Singapore Journal of Tropical Geography, 32, 220-235.

Pordata. (2011). Base de Dados de Portugal Contemporâneo [Data base of contemporary Portugal]. Retrieved November 29, 2011, from http://www.pordata.pt/Subtema/Portugal/Periodicos-16

Rakic, T., \& Chambers, D. (2012). Rethinking the consumption of places. Annals of Tourism Research, 39, 1612-1633.

Ribeiro, M. C. (2002). Empire, colonial wars and post-colonialism in the contemporary Portuguese imagination. Portuguese Studies Review, 18, 132-214.

Rose, G. (2007). Visual methodologies. An introduction to the interpretation of visual material. Los Angeles, CA: Sage.

Said, E. (1979). Orientalism. New York, NY: Vintage Books.

Said, E. (1994). Culture and imperialism. New York, NY: Vintage Books.

Saidi, H. (2008). When the past poses beside the present: Aestheticising politics and nationalising modernity in a postcolonial time. Journal of Tourism and Cultural Change, 6, 101-119.

Santos, B. S. (2002). Between Prospero and Caliban: Colonialism, postcolonialism, and inter-identity. Luso-Brazilian Review, 39(2), 9-43.

Santos, B. S. (2009). Portugal: Tales of being and not being. Portuguese Literary \& Cultural Studies, 19(20), 1-46.

Sarmento, J. (2011). Fortifications, post-colonialism and power. Ruins and imperial legacies. Farnham: Ashgate.

Schroeder, J. E. (2002). Visual consumption. London: Routledge.

Selwyn, T. (1996). Introduction. In T. Selwyn (Ed.), The tourist image: Myths and myth making in tourism (pp. 1-32). Chichester: John Wiley \& Sons.

Sharp, J. (2009). Geographies of postcolonialism. London: Sage.

Sheller, M. (2004). Demobilizing and remobilizing Caribbean paradise. In M. Sheller \& J. Urry (Eds.), Tourism mobilities: Places to play, places in play (pp. 13-21). London: Routledge.

Smith, M., \& Duffy, R. (2003). The ethics of tourism development. London: Routledge.

Stepchenkova, S., \& Morrinson, A. M. (2006). The destination image of Russia: From the online induced perspective. Tourism Management, 27, 943-956.

$\mathrm{Su}, \mathrm{X}$. (2010). The imagination of place and tourism consumption: A case study of Lijiang ancient town, China. Tourism Geographies, 12, 412-434.

Turner, L., \& Ash, J. (1975). The golden hords: International tourism and the pleasure periphery. London: Constable.

UNWTO. (2011). Tourism highlights. Retrieved July 15, 2011, from http://mkt.unwto.org/sites/all/ files/docpdf/unwtohighlights11enhr_1.pdf

Urry, J. (1995). Consuming places. London: Routledge.

Willis, S. (1991). A primer for everyday life. New York, NY: Routledge. 